JURNAL PUBLIPRENEUR: POLITEKNIK NEGERI MEDIA KREATIF

Vol.6, No. 1, Juni 2018, Doi: https://doi.org/.xxxxx, hal. 1-17

Submitted: 12 April 2018

- Revised: 13 Mei 2018

Accepted: 30 Juni 2018

\title{
PENERJEMAHAN \\ KETERAMPILAN BERBAHASA YANG BERHUBUNGAN DENGAN PROSES PENGEMBANGAN BAHASA SEBUAH TAWARAN KEWIRAUSAHAAN DALAM KEGIATAN BERBAHASA
}

\author{
Ingrid Veronica Kusumawardani, S. S., M. Pd. \\ Politeknik Negeri Media Kreatif \\ ingridvkh@yahoo.co.id
}

\begin{abstract}
This journal contains argumentation of researcher's idea on language skill which not only have an influence to language development but also entrepreneur's activity which can be executed by any person who wants to be a translator. Considering that translation is a language activity having opportunity to produce income for translator. Researcher intensively executes the research towards translation process with literature review and data analysis to gain validated data that can be accounted for because it is done in accordance with carefull and detailed observation. Researcher used descriptive methodology. In implementation, researcher used literature review for the data used resourcing from literature data, then the data analysis of this journal is qualitative analysis that is analysis of contain to data. Therefore the data was analyzed based on the level of its linkage to the problem. As for the discussion of this journal contains exposure on basis of researcher's understanding to some theories which researcher is as actor of language and entrepreneur in the field of language. In the discussion, researcher explained what needed skills are by a translator, how the relationship between translation and language development, then how big the ability of translation can be used as one of language activities which can produce income through the language activity. Therefore in the end of discussion shall be delivered all goals of this journal. Next, in conclusion and suggestion part, researcher would deliver the observation and discussion, then followed by suggestion in line with the conlucion.

Keywords: translation, culture, and entrepreneurship
\end{abstract}

e-ISSN 2723-6323

p-ISSN 2338-5049 
JURNAL PUBLIPRENEUR: POLITEKNIK NEGERI MEDIA KREATIF

Vol.6, No. 1, Juni 2018, Doi: https://doi.org/.xxxxx, hal. 1-17

Submitted: 12 April 2018

- Revised: 13 Mei 2018

Accepted: 30 Juni 2018

\section{PENDAHULUAN}

\section{Latar Belakang dan Masalah \\ A. Latar Belakang}

Perkembangan bahasa disebabkan oleh perkembangan budaya manusia. Bahasa berkembang karena akal pikiran dan aktivitas manusianya berkembang. Hal yang mendorong perkembangan itu adalah interaksi antara manusia, baik dalam satu budaya dan bahasa maupun di antara budaya dan bahasa yang berbeda.

Interaksi tersebut wajar terjadi karena manusia adalah makhluk sosial yang tidak mungkin terhindar dari relasi sosial dan budaya dengan lingkungannya. Dalam relasi tersebut komunikasi antara masyarakat satu bahasa secara lisan atau tulisan dapat dikatakan tidak menyulitkan karena masing-masing penutur atau penulis dan pembaca memahami bahasa yang digunakan.

Sebaiknya komunikasi antara masyarakat yang berbeda bahasa akan memiliki keunikan dan kesulitan tersendiri. Hal ini terjadi karena belum tentu semua anggota kelompok masyarakat yang berelasi atau berkomunikasi memahami bahasa kelompok masyarakat lainnya. Oleh sebab itu, diperlukan sarana pemahaman yang mendukung kelanjutan interaksi itu.
Pada kenyataannya

penerjemahan dapat mengatasi kesulitan pemahaman dengan mengalihbahasakan amanat dari suatu bahasa ke bahasa lainnya, sehingga memungkinkan kelangsungan relasi atau komunikasi antara masyarakat yang berbeda bahasa. Dalam fungsinya yang demikian penerjemahan berhubungan langsung dengan bahasa sumber dan bahasa sasaran. Hubungan penerjemahan dengan bahasa sumber bersifat pasif karena merupakan pemahaman amanat yang akan ditransfer ke bahasa sasaran. Sebaliknya hubungan penerjemahan dengan bahasa sasaran bersifat aktif karena apabila bagian dari bahasa sumber tidak memiliki padanan yang sesuai dalam bahasa sasaran, diperlukan usaha pencarian padanan dan pengubahan atau penambahan unsur demi kesesuaian makna yang akan diterjemahkan. Dari kenyataan tersebut timbul pertanyaan.

Bagaimana hubungan antara penerjemahan dan perkembangan Bahasa dan pengaruh timbal baliknya dengan relasi sosial budaya dan komunikasi sebagai pendukung perkembangan Bahasa, serta mampu digunakan dalam kewirausaan.

\section{B. Masalah}




\section{JURNAL PUBLIPRENEUR: POLITEKNIK NEGERI MEDIA KREATIF Vol.6, No. 1, Juni 2018, Doi: https://doi.org/.xxxxx, hal. 1-17}

Wujud dan keberadaan penerjemahan dalam interaksi dan relasi masyarakat yang meliputi bidang sosial, budaya, komunikasi, dan ilmu pengetahuan merupakan suatu situasi penting karena memberi kemudahan dan mendorong perkembangan bidang-bidang tersebut.

$$
\text { Relasi sosial budaya, }
$$
komunikasi, dan ilmu pengetahuan menggunakan bahasa sebagai sarananya. Maka yang menjadi masalah ialah "Benarkah penerjemahan merupakan suatu keterampilan berbahasa dan bagaimana pengaruh penerjemah terhadap perkembangan Bahasa dan menjadi sebuah kegiatan jasa pelayanan kewirausaan yang menjajikan?".

\section{Tujuan Penelitian}

Dalam penulisan ini ada tahapan pengumpulan, pengolahan, dan penyajian data untuk memecahkan suatu persoalan. Dengan demikian seorang peneliti pasti mempunyai tujuan dalam penelitiannya. Penelitian ini bertujuan untuk memecahkan masalah yaitu :

1. Untuk mengetahui hubungan penerjemahan dengan keterampilan berbahasa yang dapat dipergunakan dalam menjual kemampuan diri atau kewirausaan.

2. Untuk mengetahui dukungan penerjemahan dengan perkembangan Bahasa dalam konteks kewirausaan.

\section{Metode Penelitian}

a. Metode Pengumpulan Data Metode yang digunakan dalam penelitian ini adalah metode deskriptif. Dalam penerapan metode tersebut, penulis menggunakan sumber dari kepustakaan. Semua buku dan karangan lainnya dikumpulkan berdasarkan kriteria hubungannya dengan masalah penerjemahan. Dengan demikian data-data tersebut dapat menjadi pegangan dan sumber yang relevan dalam penerapan metode penelitian serta mendukung kebenaran dan keabsahan hasil penelitian.

\section{b. Metode Analisis Data}

Karena data yang digunakan bersumber dari kepustakaan, maka analisis data dalam penelitian ini adalah analisis kualitatif, yaitu analisis isi terhadap data. Dengan demikian data-data dianalisis berdasarkan tingkat keterkaitannya dengan masalah untuk kemudian disimpulkan sebagai pendukung hipotesis. 


\section{JURNAL PUBLIPRENEUR: POLITEKNIK NEGERI MEDIA KREATIF Vol.6, No. 1, Juni 2018, Doi: https://doi.org/.xxxxx, hal. 1-17}

Submitted: 12 April 2018

ロ Revised: 13 Mei 2018

Accepted: 30 Juni 2018

\section{PENERJEMAH SEBAGAI SUATU KETERAMPILAN BERBAHASA}

Penerjemahan

merupakan

pengalihan amanat dari bahasa sumber untuk memperoleh kesepadanannya dalam bahasa sasaran. Hal itu berarti bahwa dalam penerjemahan yang utama ialah kesamaan amanat dalam bahasa sumber dan bahasa sasaran.

Penerjemahan merupakan kegiatan dalam relasi sosial budaya yang membutuhkan penguasaan bahasa asing. Penerjemahan merupakan kebutuhan dalam komunikasi yang melingkupi berbagai bangsa yang berbeda bahasa. Melalui penerjemahan, suatu bangsa yang berkembang dapat menambah wawasan pengetahuan untuk menyejajarkan diri dengan bangsa-bangsa yang telah maju. Sebagai contoh dapat kita lihat bahwa buku-buku yang memuat berbagai bidang pengetahuan banyak yang masih tertulis dalam bahasa asing khususnya bahasa Inggris. Padahal kita membutuhkan informasi pengetahuan tersebut. Melalui penerjemahan, kesempatan bagi pelajar, mahasiswa, atau peminat ilmu lainnya untuk membaca dan memahaminya akan lebih mudah.

$$
\text { Melalui }
$$

penerjemahan,

informasi-informasi pengetahuan dapat diketahui oleh semua orang termasuk yang tidak atau belum menguasai bahasa-bahasa asing.

Penerjemah yang tidak ahli dapat saja menerjemahkan Duck dalam bahasa Inggris menjadi "itik", ataupun fire dalam bahasa Inggris menjadi "api" pada konteks yang seharusnya menyatakan "tembak".

Dalam kegiatannya, penerjemah harus menitikberatkan perhatian awal pada latar belakang budaya kedua bahasa demi kepastian makna dalam bahasa sumber dan penyesuaian sepadam mungkin dalam bahasa sasaran.

Dalam terjemahan, bentukbentuk seperti Good Friday diterjemahkan menjadi "Jumat Agung". Good Lord menjadi "astaga", ground-keeper menjadi "orang yang merawat lapangan atletik", broken reed menjadi "orang / sesuatu yang tidak dapat diandalkan" have a tile louse menjadi "agak gila" atau "sinting" from the ground up menjadi "seluruhnya", up in the air menjadi "tidak tentu" atau "sangat marah" hook and eye menjadi "kancing hak", dan sebagainya. Atau bentuk-bentuk lain seperti in and out menjadi "keluar masuk" bukan "dalam dan luar" cut out menjadi "berhenti bekerja" bukan "memotong ke luar", keep your finger close menjadi "berdoalah", bukan "simpan jari-

e-ISSN 2723-6323

p-ISSN 2338-5049 
JURNAL PUBLIPRENEUR: POLITEKNIK NEGERI MEDIA KREATIF Vol.6, No. 1, Juni 2018, Doi: https://doi.org/.xxxxx, hal. 1-17

jarimu dekat" atau "dekatkan jarijarimu", dan bentuk-bentuk lainnya membutuhkan perhatikan khusus demi kesesuaian makna.

Semakin berbeda budaya antara dua bahasa, semakin berbeda bahasanya, sehingga semakin sulit untuk menerjemahkan amanat dari bahasa yang satu ke bahasa lainnya karena sulit memperoleh padanan satu sama lain. Hal ini akan mempengaruhi penerjemahan dalam pencapaian tujuan yang terkadang tidak terpenuhi karena perbedaan kerangka budaya bahasa sumber dan bahasa sasaran.

Sebagai contoh dapat kita lihat bahwa suatu penerjemahan yang tujuannya memperoleh terjemahan sebagai konsekuensi mutlak bahasa sumbernya, pendekatan filologis maupun pendekatan linguistis tidak dapat dilakukan karena ditujukan pada dua bahasa yang perbedaan budayanya sangat mencolok, sehingga banyak perangkat budaya bahasa yang satu diungkapkan dalam bentuk yang berbeda dalam bahasa yang lain demi kesesuaian makna.

Keterampilan seorang penerjemah berpengaruh dalam kesuksesan kegiatan penerjemahan. Keterampilan penerjemah selayaknya mendapat perhatian khusus dan menjadi sebuah kepentingan bila kita menyadari bahwa penerjemahan membantu penambahan dan perluasan wawasan sehingga perlu ditingkatkan jumlah dan mutunya.

\section{a. Penerjemah Harus Menguasai Bahasa Asing yang Menjadi Bahasa Sumber}

Penguasaan bahasa asing yang menjadi bahasa sumber bagi seorang penerjemah adalah sebuah keharusan untuk mengatasi masalah-masalah kebahasaan dalam penerjemahan. Penguasaan meliputi masalah kebahasaan seperti gramatika, sosiolinguistik, dan sebagainya. Pengetahuan gramatika perlu dimiliki karena ketepatan pemahaman tatabahasa mempengaruhi ketepatan pemahaman makna. Sedangkan pengetahuan sosiolinguistik diperlukan untuk memperoleh pemahaman yang tepat terhadap makna dan gaya akan dipindahbahasakan. Dalam hal ini pemahaman akan memudahkan penerjemahan karena penerjemah mengetahui jenis atau bentuk bahasa berupa bahasa resmi, slang, jargon, dan sebagainya, sehingga dengan tepat memindahkannya ke bahasa sasaran.

\section{b. Penerjemah harus menguasai bahasa sasaran secara sempurna}

e-ISSN 2723-6323

p-ISSN 2338-5049 


\section{JURNAL PUBLIPRENEUR: POLITEKNIK NEGERI MEDIA KREATIF Vol.6, No. 1, Juni 2018, Doi: https://doi.org/.xxxxx, hal. 1-17}

Penguasaan bahasa sasaran juga merupakan hal yang harus dimiliki penerjemah

karena ketidaksempurnaannya dapat menyesatkan penerjemahan. Dengan penguasaan yang sempurna terhadap bahasa sasaran seorang penerjemah akan lebih mudah melakukan penerjemahan karena lebih mudah memilih padanan yang sesuai dalam bahasa sasaran.

\section{c. Penerjemah Harus Menguasai Materi yang akan diterjemahkan}

Penguasaan ini penting karena tanpa pemahaman mengenai hal yang ia terjemahkan, seorang penerjemah akan mengalami kebimbangan dalam menentukan maksud suatu kata, kalimat, atau bahkan maksud keseluruhan makna dari bahasa sumber. Kebimbangan tersebut dapat menyebabkan penerjemah akhirnya menyimpulkan makna berdasarkan perkiraan atau penafsiran yang tidak pasti atau menerka-nerka. Maka hasilnya mungkin saja sebuah kekeliruan atau ketidaktepatan makna karena makna itu berada di luar jangkauan pengetahuan atau pengalaman penerjemah.

\section{d. Penerjemah harus menguasai metode dan teknik penerjemah}

Seorang penerjemah harus menguasai metode dan teknik penerjemahan yang sumber acuannya dapat dipilih berdasarkan tujuan atau sasaran yang akan mendukung ketepatan pemahaman makna, sehingga diperoleh hasil penerjemahan yang baik dan mengenai sasaran.

Contoh yang menunjukkan pernyataan itu dapat kita lihat bahwa dalam bahasa Inggris kata sleep dan sleepy mempunyai kemiripan bentuk. Sedangkan padanannya dalam bahasa Indonesia yaitu kata "tidur" dan "mengantuk" tidak mempunyai kemiripan bentuk sama sekali. Begitu juga pembentukan ly dalam bahasa Inggris pada kata-kata seperti quick menjadi quickly, soft menjadi softly, calm menjadi calmly, yang padanannya dalam bahasa Indonesia adalah "dengan", maka jika ly dalam bahasa Inggris diterangkan pada akhir kata secara senyawa, dalam bahasa Indonesia "dengan" diterangkan di depan kata secara terpisah, yaitu "dengan cepat" (quickly), "dengan lembu" (softly), "dengan tenang" (calmly). Hal tersebut menunjukkan ciri khusus bahasa Inggris dan bahasa Indonesia.

Contoh lain dapat kita lihat bahwa dalam bahasa Inggris berlaku hukum MD, sehingga kata pretty dalam pretty girl ditempatkan

e-ISSN 2723-6323 p-ISSN 2338-5049 
JURNAL PUBLIPRENEUR: POLITEKNIK NEGERI MEDIA KREATIF Vol.6, No. 1, Juni 2018, Doi: https://doi.org/.xxxxx, hal. 1-17

ditempatkan di depan karena menerangkan kata girl yang diterangkan. Sedangkan dalam bahasa Indonesia berlaku hukum DM, sehingga kata "cantik" dalam "gadis cantik" ditempatkan di belakang karena menerangkan "gadis" yang diterangkan.

Hal-hal yang menyangkut kekodratan bahasa seperti di ataslah yang harus dipahami dan disadari oleh seorang penerjemah agar dapat melaksanakan penerjemahan dengan baik tanpa memaksakan bentuk bahasa sumber ke bentuk bahasa sasaran yang berbeda ciri pembentukannya. 
JURNAL PUBLIPRENEUR: POLITEKNIK NEGERI MEDIA KREATIF

Vol.6, No. 1, Juni 2018, Doi: https://doi.org/.xxxxx, hal. 1-17

Submitted: 12 April 2018

nevised: 13 Mei 2018

Accepted: 30 Juni 2018

\begin{abstract}
PENERJEMAHAN
BERHUBUNGAN

PERKEMBAGAN BAHASA

Sebelum mengutarakan bahwa penerjemahan berhubungan dengan perkembangan bahasa, disampaikan terlebih dahulu unsur - unsur yang mempengaruhi perkembangan Bahasa, sebagai berikut :
\end{abstract}

\section{Unsur-unsur yang Mempengaruhi Perkembangan Bahasa}

\section{Relasi Sosial Budaya}

Bahasa merupakan bagian integral dan paling dominan dalam relasi sosial budaya karena meliputi dan berfungsi bagi seluruh bagian dari relasi itu untuk mewujudkannya menjadi utuh dan berkembang.

Hal ini dapat kita lihat dalam penambahan kosa kata bahasa Indonesia sebagai akibat dari relasi sosial budaya. Misalnya pemungutan nama-nama jenis musik seperti zaji, rock, metal, slow rock, dan sebagainya. Ataupun jenis makanan seperti burger, hot dog, pizza, ice cream, yang semula bukan merupakan hasil budaya bangsa Indonesia. Juga kata-kata lain seperti hockey kiper (dari kata keeper), raket (dari kata racket), zebra cross, dan kata-kata lainnya yang telah menjadi milik bahasa Indonesia. Semua contoh tersebut menunjukkan pengaruh bahasa yang terjadi karena relasi sosial budaya masyarakatnya.

2. Perkembangan Akal Pikiran dan Ilmu Pengetahuan Manuisa

Kenyataan menunjukkan bahwa akal pikiran manusia yang pada dasarnya berhubungan dengan bahasa, melalui proses berpikir akan menghasilkan pengetahuan yang akhirnya mempengaruhi perkembangan bahasa yang digunakan. Oleh sebab itu, dengan bertambah majunya ilmu pengetahuan manusia, bahasa yang digunakan untuk mengungkapkan akan berkembang pula. Hal tersebut akan berlangsung terus selama kegiatan berpikir dan kemajuan ilmu pengetahuan manusia terus berkembang.

\section{Penerjemahan Sebagai Sarana Pengembangan Relasi Sosial Budaya}

Relasi sosial dan budaya adalah suatu aktivitas manusia yang tidak dapat mengabaikan bahasa. Hal tersebut disebabkan setiap pranata kehidupan manusia menggunakan bahasa sehingga relasi sosial budaya yang merupakan relasi berbagai pranata kehidupan manusia hanya mungkin terlaksana jika ada bahasa sebagai sarananya. Dalam hal ini tukar-menukar informasi pengetahuan, benda-benda seni, e-ISSN 2723-6323 p-ISSN 2338-5049 
JURNAL PUBLIPRENEUR: POLITEKNIK NEGERI MEDIA KREATIF Vol.6, No. 1, Juni 2018, Doi: https://doi.org/.xxxxx, hal. 1-17

kesenian, kepercayaan, dan sebagainya yang terjadi dalam relasi sosial budaya menggunakan bahasa sebagai sarananya.

Negara berkembang biasanya melakukan penyerapan unsur-unsur bahasa bangsa yang telah maju dengan mengambil ciri-ciri budayawan. Hal tersebut terlaksana karena adanya pemahaman amanat antara kedua bangsa yang berelasi itu. Dalam hal inilah penerjemahan menjadi sarana yang cukup memadai di samping kemahiran berbahasa asing.

\section{Penerjemahan Sebagai Sarana Pengembangan Komunikasi}

Bahasa sangat berperan dan berpengaruh dalam pengiriman dan penerimaan pesan yang dilakukan manusia. Pengiriman dam penerimaan pesan tersebut semakin berkembang meliputi berbagai jenis komunikasi antar segala kelompok manusia yang berasal dari satu suku bangsa / bahasa maupun dari yang berbeda suku bangsa / bahasa.

Maka pilihan lain yang dapat mengatasinya ialah penerjemahan, yaitu pengalihan bahasa terhadap pesan yang dikirim ke dalam bahasa penerima. Dengan demikian komunikasi dapat berjalan dengan baik karena adanya pemahaman antara kedua belah pihak yang berkomunikasi.

\section{Penerjemahan Sebagai Sarana Pengembangan Ilmu Pengetahuan}

Ketepatan penerjemahan menyokong pemahaman pembaca dan membuka kesempatan pengembangan pengetahuannya. Kita dapat memperoleh pengetahuanpengetahuan baru dengan segera, kita dapat mengejar perkembangan pengetahuan dunia. Maka cara yang paling efektif ini tentu saja harus diiringi kemauan membaca, sehingga keefektifannya tidak terhalang oleh ketidakmahiran kita menggunakannya. Dengan demikian ketidakmahiran / ketidakpahaman bahasa asing tidak menjadi hambatan pemerolehan ilmu pengetahuan baru dan pengembangannya.

Bukti yang membenarkan pernyataan di atas dapat kita lihat dari hasil-hasil penerjemahan mengenai berbagai bidang ilmu pengetahuan. Misalnya buku The new book of populer science (Graham, 1981) yang isinya dikarang oleh beberapa pengarang / ilmuwan Amerika, diterjemahkan oleh Cayne dkk, (1986) menjadi "Ilmu Pengetahuan Populer", sehingga dapat segera dipahami oleh pemakai bahasa Indonesia. 


\section{JURNAL PUBLIPRENEUR: POLITEKNIK NEGERI MEDIA KREATIF Vol.6, No. 1, Juni 2018, Doi: https://doi.org/.xxxxx, hal. 1-17}

Submitted: 12 April 2018

- Revised: 13 Mei 2018

Accepted: 30 Juni 2018

\begin{abstract}
Berdasarkan hal tersebut, terlihat bahwa penerjemahan merupakan salah satu sarana pengembangan ilmu pengetahuan yang dapat segera memberi informasi pengetahuan.
\end{abstract}

\section{Penerjemahan Berhubungan dengan Perkembangan Bahasa}

Sejarah membuktikan bahwa sejak abad ke tiga Siswa dapat menyebutkan, sudah ada kegiatan penerjemahan, yaitu penerjemahan kitab suci bahasa Ibrani ke dalam bahasa Yunani. Hal ini berarti bahwa penerjemahan karya tulis seiring dengan perkembangan bahasa tulis. Dalam masa perkembangannya penerjemahannya menjadi kegiatan yang banyak diminati orang. Apalagi ternyata terjemahan tulisan-tulisan kuno dan karya-karya bahasa asing sangat dibutuhkan sekarang ini. Tulisan-tulisan kuno berguna untuk kepentingan sejarah dan budaya. Sedangkan karya-karya tulis dalam bahasa asing terutama yang memuat bidang-bidang pengetahuan berguna untuk pengembangan pengetahuan bangsa.

Penerjemahan dapat dikatakan hampir bersamaan fungsinya dengan kemahiran berbahasa asing karena keduanya memungkinkan terjadinya dan membantu pengembangan relasi sosial budaya, komunikasi, dan ilmu pengetahuan.

Bukti lain yang menunjukkan hal tersebut di atas, dapat kita lihat dari kata-kata yang memiliki pola bunyi yang semula tidak dimiliki bahasa Indonesia (bahkan sebagian belum tertera dalam KBBI namun menjadi unsur serapan dalam hasil penerjemahan, sebagai berikut :

\begin{tabular}{|l|l|}
\hline \multicolumn{1}{|c|}{ Bahasa Inggris } & \multicolumn{1}{|c|}{$\begin{array}{c}\text { Bahasa } \\
\text { Indonesia }\end{array}$} \\
\hline $\begin{array}{l}\text { Radar } \\
\text { astronomy } \\
\text { (Graham, I, 1981: } \\
\text { 67). }\end{array}$ & $\begin{array}{l}\text { Astronomiradar } \\
\text { (Cayne, I, 1986 : } \\
\text { 61) }\end{array}$ \\
\hline $\begin{array}{l}\text { Magnetosphere } \\
\text { (Graham, I, 1981: } \\
\text { 96) }\end{array}$ & $\begin{array}{l}\text { Magnestefer } \\
\text { (Cayne, I, 1986 : } \\
\text { 96) }\end{array}$ \\
\hline $\begin{array}{l}\text { Declination } \\
\text { (Graham, I, 1981: } \\
\text { 23) }\end{array}$ & $\begin{array}{l}\text { Deklinasi } \\
\text { (Cayne, I, 1986 : } \\
\text { 23) }\end{array}$ \\
\hline $\begin{array}{l}\text { Spectroscope } \\
\text { (Graham, I, 1981: } \\
\text { 20) }\end{array}$ & $\begin{array}{l}\text { Spektroskop } \\
\text { (Cayne, I, 1986 : } \\
\text { 20) }\end{array}$ \\
\hline $\begin{array}{l}\text { Circumpelar } \\
\text { (Graham, I, 1981: } \\
\text { 20) }\end{array}$ & $\begin{array}{l}\text { Sirkumpolar } \\
\text { (Cayne, I, 1986 : }\end{array}$ \\
\hline $\begin{array}{l}\text { Soltice } \\
\text { (Graham, I, 1981: } \\
\text { 24) }\end{array}$ & $\begin{array}{l}\text { Solstis } \\
\text { (Cayne, I, 1986 : } \\
\text { 24) }\end{array}$ \\
\hline $\begin{array}{l}\text { Precession } \\
\text { (Graham, I, 1981: } \\
\text { 24) }\end{array}$ & $\begin{array}{l}\text { Presesi } \\
\text { (Cayne, I, 1986 : } \\
\text { 24) }\end{array}$ \\
\hline $\begin{array}{l}\text { Interferometer } \\
\text { (Graham, I, 1981: }\end{array}$ & $\begin{array}{l}\text { Interferometer } \\
\text { (Cayne, I, 1986 : }\end{array}$ \\
\hline & e-ISSN 2723-6323 \\
p-ISSN 2338-5049
\end{tabular}




\section{JURNAL PUBLIPRENEUR: POLITEKNIK NEGERI MEDIA KREATIF Vol.6, No. 1, Juni 2018, Doi: https://doi.org/.xxxxx, hal. 1-17}

Submitted: 12 April 2018

nevised: 13 Mei 2018

Accepted: 30 Juni 2018

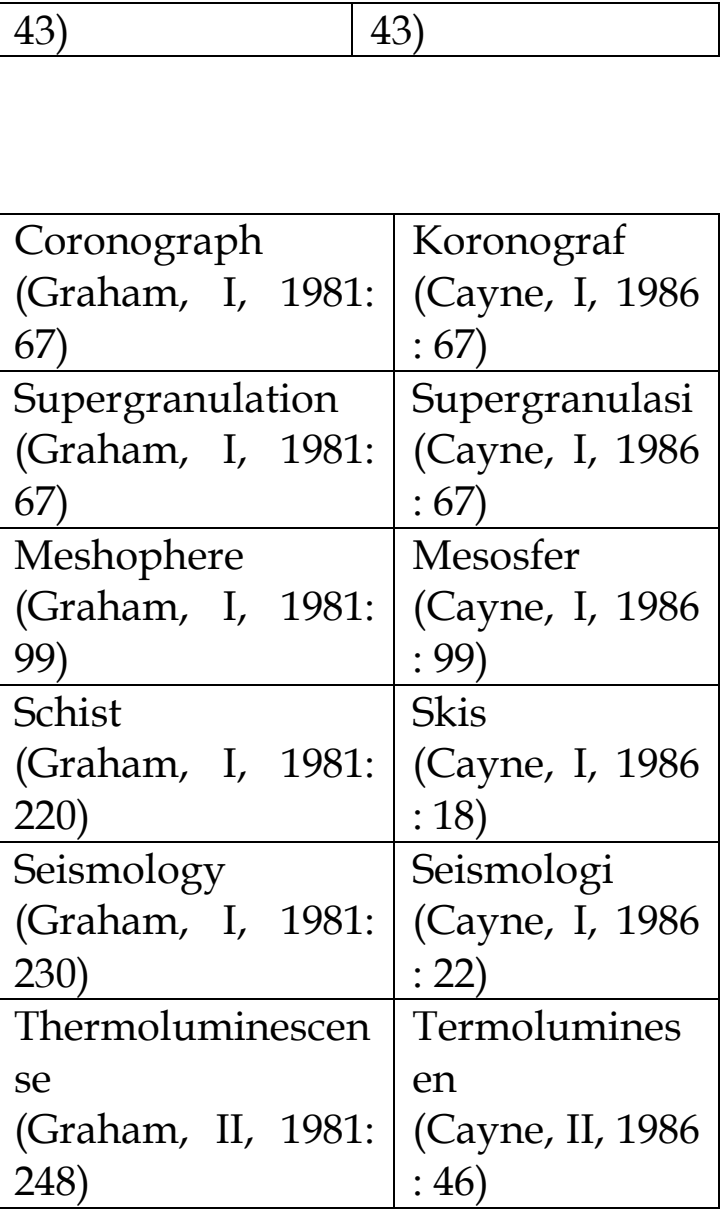

dan sebagainya.

Kesemua contoh di atas menunjukkan bahwa masuknya unsur serapan yang telah resmi menjadi unsur bahasa Indonesia ataupun yang belum (namun lazim digunakan), mempengaruhi / menambah gugus bunyi bahasa Indonesia. Dengan kata lain, penerjemahan yang merupakan salah satu sarana pengembangan relasi sosial budaya, komunikasi, dan ilmu pengetahuan memungkinkan penambahan bunyi dan tata bunyi bahasa sasarannya. Selanjutnya penambahan unsur-unsur tersebut merupakan bagian dari dan penyokong bagi pengembangan bahasa itu.

Contohnya kata stony irons (Graham I, 1981 : 165) tidak harus diterjemahkan menjadi "berbatu-batu besi" atau "besi berbatu-batu", melainkan lebih tepat jika diterjemahkan menjadi "besi bercampur batu" (Cayne, I, 1986 : 165), atau kata spechrostopis binaries (Graham, I, 1981, 24) tidak harus diterjemahkan menjadi "spechrostopis kembar / berpasangan" atau "pasangan spechrostopis" melainkan lebih tepat jika diterjemahkan menjadi "bintang binar spektroskopik" (Cayne, I, 1986 : 24). Dengan demikian dapat disimpulkan bahwa dalam penerjemahan yang terpenting adalah kesamaan makna yang diungkapkan, bukan semata-mata kesamaan bentuk (kecuali pada penerjemahan yang mempunyai tujuan kesamaan bentuk secara mutlak demi kepentingan tertentu).

Kategori jumlah merupakan hal yang agak sulit dipadankan antara bahasa Inggris dan bahasa Indonesia karena keduanya memiliki perbedaan mengenainya. Dalam bahasa Inggris

e-ISSN 2723-6323

p-ISSN 2338-5049 


\section{JURNAL PUBLIPRENEUR: POLITEKNIK NEGERI MEDIA KREATIF Vol.6, No. 1, Juni 2018, Doi: https://doi.org/.xxxxx, hal. 1-17}

bentuk jamak dinyatakan dengan dua cara, yaitu menerangkan fonem / s / pada akhir kata bentuk Countable nouns seperti pens, rulers, tigers, dan sebagainya, dan dengan tidak menerangkan fonem / s / pada bentuk Uncountable nouns seperti sugar, salt, rice, water, dan sebagainya. Dalam bahasa Indonesia bentuk jamak umumnya dinyatakan dengan bentuk perulangan atau penambahan unsur penunjuk jumlah seperti tiga, empat, tujuh, seratus (penunjuk jumlah tentu), dan sedikit, beberapa, para, semua, kaum, himpunan, sekelompok, sejumlah (penunjukan jumlah tak tentu). Hal demikian yang oleh Widyamartaya (1989: 45) dikatakan, "Bentuk jamak dalam bahasa Indo - Jerman, misalnya bahasa Inggris, tidak selalu harus diterjemahkan menjadi bentuk ulang (bentuk reduplikasi) dalam bahasa Indonesia". Maka kata-kata seperti donators, tourist, soldiers cukup diterjemahkan menjadi "penderma", "wisatawan", "prajurit" karena dengan demikian sudah mewakili makna jamak dari bahasa sumber. Hal ketidakkonsistenan demikianlah yang menimbulkan masalah dalam penerjemahan. Oleh sebab itu, diperlukan keterampilan penerjemah untuk memperoleh ketepatan makna yang diterjemahkan.
Salah satu kategori gramatis yang juga perlu diperhatikan dalam penerjemahan amanat dari bahasa Inggris ke bahasa Indonesia adalah kategori gramatis persona. Berikut akan diterangkan tabel yang menunjukkan perbedaan kategori persona antara bahasa Inggris dan bahasa Indonesia.

\begin{tabular}{|l|l|}
\hline \multicolumn{1}{|c|}{$\begin{array}{c}\text { Kategori } \\
\text { Gramatis } \\
\text { Persona Bahasa } \\
\text { Inggris }\end{array}$} & $\begin{array}{c}\text { Kategori } \\
\text { Gramatis } \\
\text { Persona Bahasa } \\
\text { Indonesia }\end{array}$ \\
\hline I & Saya, aku \\
\hline You & $\begin{array}{l}\text { Kamu, kau / } \\
\text { engkau, anda }\end{array}$ \\
\hline She atau he & Dia, ia \\
\hline We & Kita atau kami \\
\hline They & Mereka \\
\hline
\end{tabular}

Hal di atas menunjukkan bahwa dalam bahasa Inggris bentuk orang ketiga tunggal dibedakan atas jenis kelamin, sedangkan dalam bahasa Indonesia tidak. Sebaliknya untuk kata pengganti bentuk jamak dalam bahasa Indonesia dibedakan kata "kami" dan "kita", sedangkan dalam bahasa Inggris hanya ada kata we saja untuk menyatakan kata ganti jamak tersebut. Dengan demikian dapat dikatakan bahwa masalah perbedaan kategori gramatis persona merupakan hal yang perlu diperhatikan dalam penerjemahan untuk memperoleh hasil terjemahan yang tepat makna

e-ISSN 2723-6323

p-ISSN 2338-5049 


\section{JURNAL PUBLIPRENEUR: POLITEKNIK NEGERI MEDIA KREATIF Vol.6, No. 1, Juni 2018, Doi: https://doi.org/.xxxxx, hal. 1-17}

dan tidak mengganggu kaidah bahasa sasaran.

Masalah berikutnya ialah tata kalimat. Dalam hal ini usaha untuk menyamakan panjang pendeknya kalimat dari bahasa sumber ke bahasa sasaran bukanlah suatu keharusan. Karena belum tentu kalimat yang panjang dalam bahasa sasaran, atau kalimat yang pendek dalam bahasa sumber memiliki padanan dalam bahasa sasaran. Melainkan mungkin saja sebaliknya. Oleh sebab itu, penerjemahan dengan tujuan memperoleh konsekuensi mutlak bahasa sumber, tidaklah menjamin ketepatan makna. Sebaliknya penerjemahan yang memperhatikan segala segi kebahasaan dan bidang yang diterjemahkan lebih mungkin menghasilkan padanan amanat yang paling sesuai dengan amanat dalam bahasa sumber. Kesesuaian tersebut akan menyebabkan tanggapan yang relatif sama antara bahasa submer dan bahasa sasaran. Dan bila amanat itu belum dimiliki bahasa sasaran, pemadanannya akan mempengaruhi perkembangan bahasa dalam hal penambahan unsur-unsurnya.

Ketiadaan unsur kata untuk mewakili makna dari bahasa sumber biasanya disebabkan ketiadaan unsur budaya yang demikian dalam bahasa sasaran. Hal ini dapat diatasi dengan cara menyerap (bentuk asli atau penyesuaian), menerjemahkan, dan mencari padanannya dalam bahasa sasaran dengan menciptakan padanan tersendiri.

Persoalan idiomatik dalam leksikoin penerjemahan umumnya disebabkan perbedaan budaya antara bahasa sumber dan bahasa sasaran. Misalnya bentuk raining cat and dong tidak dapat diterjemahkan kata demi kata menjadi "hujan kucing dan anjing", melainkan "hujan seperti dicurahkan dari langit", melainkan "hujan seperti dicurahkan dari langit" sesuai maknanya dalam bahasa sumber. Juga bentuk many times yang tidak tepat jika diterjemahkan menjadi "banyak waktu", melainkan "sering sekali" sesuai maknanya dalam bahasa sumber.

Munculnya unsur-unsur baru dalam hasil kegiatan penerjemahan akan memperluas ruang lingkup bahasa sasaran itu jika adanya kesepakatan dan kekonsistenan cara dan sarana untuk mengatasi masalah kebahasaan yang timbul karena perbedaan budaya.

Akhirnya dapat disimpulkan bahwa penerjemahan mempunyai hubungan timbal balik dengan perkembangan bahasa, karena penerjemahan yang pada dasarnya membutuhkan dan mengakibatkan kelengkapan unsur itu memungkinkan terjadinya usaha e-ISSN 2723-6323 p-ISSN 2338-5049 


\section{JURNAL PUBLIPRENEUR: POLITEKNIK NEGERI MEDIA KREATIF}

Vol.6, No. 1, Juni 2018, Doi: https://doi.org/.xxxxx, hal. 1-17

perlengkapan unsur-unsur.

Sebaliknya perkembangan bahasa semakin memperlancar kegiatan penerjemahan karena unsur-unsur bahasa yang akan mewakili amanat yang diterjemahkan. 


\section{JURNAL PUBLIPRENEUR: POLITEKNIK NEGERI MEDIA KREATIF Vol.6, No. 1, Juni 2018, Doi: https://doi.org/.xxxxx, hal. 1-17}

Submitted: 12 April 2018

nevised: 13 Mei 2018

Accepted: 30 Juni 2018

\section{SIMPULAN DAN SARAN}

\section{A. Simpulan}

Penerjemahan disebut sebagai keterampilan berbahasa karena berwujud pengaplikasian ilmu-ilmu bahasa ke dalam kegiatan pengalihbahasaan. Hal ini terlihat pada proses penerjemahan yang dalam setiap langkahnya yaitu penjagaan, penguraian, pemahaman, peristilahan, perakitan, pengecekan, dan pembicaraan, tidak terlepas dari bahasa dan masalah-masalahnya. Dengan kata lain, walaupun tujuan penerjemahan menentukan pendekatan yang digunakan, kemudian pendekatan itu menghasilkan jenis terjemahan, namun keterampilan penerjemahlah yang menentukan ketepatan / kesesuaian hasil penerjemahan dengan tujuan yang mendasarinya.

Anggapan bahwa penerjemahan berhubungan dengan perkembangan bahasa adalah benar. Dinyatakan benar karena relasi sosial budaya, komunikasi, dan ilmu pengetahuan sebagai bidang yang membutuhkan penerjemahan, memungkinkan penerjemahan membutuhkan unsurunsur baru yang tidak dijumpai dalam budaya / bahasa sasarannya. Kebutuhan itu akan mengakibatkan munculnya unsur-unsur baru dalam bahasa sasaran untuk dapat secara lengkap mewakili amanat dari bahasa sumber. Penambahan unsur-unsur baru tersebut akan memperkaya bahasa itu dan memperluas ruang lingkup lingkungan dalam mewakili berbagai amanat / budaya.

Dengan kata lain, penerjemahan dikatakan sebagai suatu keterampilan berbahasa karena penerjemahan merupakan wujud dari keterampilan berbahasa. Hubungan penerjemahan dengan perkembangan bahasa terjadi karena fungsinya dalam pengembangan relasi sosial budaya, komunikasi, dan ilmu pengetahuan sebagai unsur-unsur yang mempengaruhi perkembangan bahasa, memungkinkannya untuk mempunyai hubungan dengan perkembangan bahasa. Hubungan tersebut berupa keharusan bahasa melengkapi diri sehingga mampu mengungkapkan hal-hal di luar budayanya, dan kemudahan bagi penerjemahan bila unsur-unsur itu semakin lengkap.

Selanjutnya, dengan memiliki kemampuan sebagai penerjemah, seseorang dapat menjadi seorang wirausaha yang dapat menjual kemampuan dirinya sebagai sebuah jasa layanan kebahasaan yang relatif menguntungkan secara ekonomi karean merupakan suatu keterampilan yang langka dan berharga. 


\section{JURNAL PUBLIPRENEUR: POLITEKNIK NEGERI MEDIA KREATIF Vol.6, No. 1, Juni 2018, Doi: https://doi.org/.xxxxx, hal. 1-17}

\section{B. Saran}

Penerjemahan selayaknya mendapat perhatian khusus dari pemerintah, para penerjemahan, dan kaum intelektual bahasa karena berfungsi bagi pengembangan relasi sosial budaya, komunikasi, dan ilmu pengetahuan. Perhatikan itu seharusnya meliputi jumlah dan mutu hasil penerjemahan, sehingga usaha pengembangan ketiga bidang tersebut menjadi suatu usaha yang berhasil guna secara positif, yaitu berguna bagi pengembangan relasi sosial budaya, komunikasi, dan ilmu pengetahuan karena kebenaran informasi yang diterjemahkan, dan ilmu pengetahuan karena kebenaran informasi yang diterjemahkan, dan berguna bagi perkembangan bahasa sasaran yang harus mewakili amanatnya.

Seorang penerjemah hendaknya mewakili kriteria penerjemah ideal untuk dapat menghasilkan terjemahan yang baik sesuai tujuan penerjemahan. Hal ini untuk meningkatkan kemampuannya sehingga dapat memeperoleh keuntungan yang lebih tinggi dalam kewirausaan.

DAFTAR PUSTAKA
Alwasilah, A. Chaedar. 1989.

Sosiologi Bahasa. Bandung :

Angkasa.

Anwar Khaidir. 1984. Fungsi dan

Peranan Bahasa - Sebuah

Pengantar. Yogyakarta.

Universitas Gajah Mada.

Cayne Berbard S. dkk. 1981. The New

Book of Populer Science.

Jakarta : PT. Intermasa.

Chaer. Abdul. 1986. Kamus Idiom Bahasa Indonesia. Flores : Nusa Indah.

Chauchard, Paul. 1983. Bahasa dan Pikiran. Yogyakarta : Kanisius.

Departemen Pendidikan dan

Kebudayaan. 1990. KBBI.

Jakarta : PN. Balai Pustaka.

Echols, John. M. dan Hasan Shadily.

1979. Kamus Inggris Indonesia.

Jakarta: Gramedia.

Feisal. Jusuf A. 1985. Bahasa Indonesia Menghadapi

Penerjemahan dalam Kongres

Bahasa Indonesia IV. Jakarta

Pusat Pembinaan dan

Pengembangan Bahasa.

Graham, Howard B. dkk. 1986. Ilmu Pengetahuan Populer. U.S.A. : Grolier.

Hasibuan, H. Sofia Rangkuti 1990.

Teori Terjemahan dan

Kaitannya dengan Tatabahasa Inggris. Jakarta : Dian Rakyat.

e-ISSN 2723-6323

p-ISSN 2338-5049 


\section{JURNAL PUBLIPRENEUR: POLITEKNIK NEGERI MEDIA KREATIF Vol.6, No. 1, Juni 2018, Doi: https://doi.org/.xxxxx, hal. 1-17}

Kamil, R. AG. Teknik Membaca Textbook dan Penerjemahanu. Yogyakarta : Kanisius.

Kridalaksana, Harimurti. 1985. Fungsi Bahasa dan Sikap Bahasa. Flores : Nusa Indah.

Jakarta : Gramedia. 1984. Kamus Linguistik.
Larson, Milders 1989. Penerjemahan Berdasar Makna : Pedoman Untuk Pemadanan Antar Bahasa. Jakarta : Armico. Lunandi, AG. 1990. Komunikasi Mengena. Yogyakarta : Kanisius.

Moelino, Anton M. 1989. Kembara Bahasa - Kumpulan Karangan Tersebaru. Jakarta : Gramedia.

Purwo, Bambang Kaswanti. 1990. PELLBA 3 - Pertemuan Linguistik Lembaga Bahasa Atmajaya Ketiga. Jakarta : Kanisius. . 1986. Pusparagam Linguistik dan Pengajaran Bahasa. Jakarta : Arcan.

Pusat Pembinaa dan Pengembangan Bahasa. 1990. Pedoman Umum Ejaan Bahasa Indonesia. Jakarta : PN. Balai Pustaka. . 1989. Pedoman Umum Pembentukan Istilah. PN. Balai Pustaka.

Salim, Peter. 1988. Anvaced Dictionary of Idioms English
Indonesia. Jakarta: Modern English Press.

Samsuri. 1981. Analisis Bahasa. Jakarta : Erlangga.

Sapir, Edward. 1949. Language. New York : Harvest / HBJ.

Soegeng Jsh, AY. Dan Madya Ekosusilo. 1988. Pedoman Penerjemahan. Semarang : Effar Offset.

Soesilo, Daud H. 1990. Aneka Pendekatan di Dalam Penerjamahan : Sebuah Tinjauan dalam PELLBA 3. Yogyakarta : Kanisius.

Sukapiring. Peraturan. 1989.

Pedoman Penulisan Karya Ilmiah. Medan : Fakultas Sastra USU.

Susanto, Phil Astrid. 1974. Komunikasi Dalam Teori dan Praktek. Jilid I - II. Bandung : Binacipta.

Tarigan, Henry Guntur. 1984. Psikolinguistik. Bandung : Angkasa.

Widyamartaya. A. 1989. Seni Menerjemahkan. Yogyakarta : Kanisius. 